\title{
Epoprostenol for very low birth weight (VLBW) infants: a novel dilution protocol.
}

\author{
Epoprostenolo per neonati di bassissimo peso alla nascita, un nuovo protocollo di diluizione
}

S. Rugolotto, ${ }^{1}$ R. Beghini, ${ }^{1}$ I. Cogo,${ }^{1}$ G. Sidoti, ${ }^{1}$ E. M. Padovani, ${ }^{1}$ A. Pietrobelli ${ }^{1}$

Key words: epoprostenol, very low birth weight infants, infants

\section{Riassunto}

L'epoprostenolo è stato il primo trattamento efficace per l'ipertensione arteriosa grave. L'epoprostenolo è fornito in fiale per la terapia di pazienti adulti. Non sono specificati in letteratura protocolli di diluizione specifici per neonati di peso molto basso alla nascita (VLBW), nei quali sono richieste velocità di infusione molto basse.

Descriviamo il protocollo di diluizione che è stato applicato ad un neonato pretermine nato alla 30 settimana gestazionale con un peso di $1.000 \mathrm{~g}$.. Il nostro protocollo di diluizione mantiene i rapporti di diluizione raccomandati, il $\mathrm{pH}$ richiesto della soluzione per dosaggi molto bassi di epoprostenolo, usando la stessa fiala di diluente. Il nostro metodo permette una somministrazione sicura di epoprostenolo in neonati con peso molto basso alla nascita.

\section{Abstract}

Epoprostenol has been the first effective treatment for severe pulmonary arterial hypertension. Epoprostenol is provided in vials for adult therapy. To our knowledge there are no reports on specific dilution protocols for epoprostenol in VLBW infants, when very small infusion rates are required.

\footnotetext{
Department of Pediatrics - Section of Newborn Intensive Care Unit - Azienda Ospedaliera Universitaria Integrata di Verona, Italy
}

Indirizzo per la corrispondenza (Corresponding author):

Simone Rugolotto, MD

Department of Pediatrics - Section of Newborn Intensive Care Unit

Azienda Ospedaliera Universitaria Integrata di Verona.

P.le L. A. Scuro, 10 - 37134 Verona - Italy

Tel: +390458124390 - fax: +390458124746

email: simone.rugolotto@ospedaleuniverona.it
We describe the dilution protocol we applied to a preterm infant who was born at 30 weeks of gestational age with a weight of $1.000 \mathrm{~g}$. Our dilution protocol keeps the recommended dilution ratios, and the required solution $\mathrm{pH}$, for very small dosages of epoprostenol, using the same diluent vial. Our method allows a correct and safe administration of epoprostenol in VLBW infants.

\section{Introduction}

Epoprostenol $\left(\right.$ Flolan ${ }^{\circ}$ ) has been the first effective treatment for severe pulmonary arterial hypertension. ${ }^{1,2}$ It is a potent, short-acting, vasodilating prostacyclin, which has been shown to improve hemodynamics, exercise capacity, and survival both in adults and in children. $^{3}$

Epoprostenol is provided in vials for adult therapy. This has two potential consequences in children and infants: medication errors, ${ }^{4}$ and increased costs due to drug waste, ${ }^{5}$ when more vials must be used for treatment even though small amount of drug are needed. To our knowledge there are no reports on specific dilution protocols for epoprostenol in VLBW infants, when very small infusion rates are required.

\section{Case Report}

We describe the dilution protocol we applied to a preterm infant who was born at 30 weeks of gestational age with a weight of 1.000 g. He was affected with pulmonary hypoplasia, intra-uterine growth retardation and severe pulmonary hypertension. At 10 days of life he was treated with mechanical ventilation, inotropes, $\mathrm{NO}, \mathrm{FiO} 2$ $100 \%$, and HFOV. Because of persistent hypoxia, in order to maximize its therapy for pulmonary hypertension, after having obtained parents' consent, we started also epoprostenol.

Flolan ${ }^{\circ}$ is an unstable compound which must be prepared every 12 hrs $\left(24 \mathrm{hrs}\right.$ when cooled at $\left.<20^{\circ} \mathrm{C}\right)$. It requires in each patient a precise titration upwards according to the clinical response, starting 
with $2 \mathrm{ng} / \mathrm{kg} / \mathrm{min}$. It must be reconstituted with a sterile diluent supplied in glass vials containing $50 \mathrm{ml}$ of $94 \mathrm{mg}$ glycine, $73.3 \mathrm{mg}$ sodium chloride, sodium hydroxide (added to adjust $\mathrm{pH}$ ), and water for injection, usp. The reconstituted solution of Flolan ${ }^{\circ}$ has a $\mathrm{pH}$ of 10.2 to 10.8 and is increasingly unstable at a lower $\mathrm{pH}$. Since Flolan vials are prepared for adults, when given to small infants, its dosage and administration is somewhat challenging due to a fixed minimum diluted solution $(250 \mathrm{ng} / \mathrm{mL})$, and a vial cointaining $500.000 \mathrm{ng}$ of dry powder. In order to keep the $\mathrm{pH}$ of the solution in the correct range, a fixed maximum amount of normal saline can be added to dilute the drug solution, according to the rate 6:1. Figure 1 shows the dilution protocol we applied.

For our patient, dosages and infusion rates $(\mathrm{ml} / \mathrm{hr})$ were calculated according the following formula:

Infusion rate $(\mathrm{mllhr})=60 \times$ dosage $(\mathrm{ng} / \mathrm{kg} / \mathrm{min}) \times$ bodyweight $(\mathrm{kg}) /$ solution's concentration $(\mathrm{ng} / \mathrm{ml})$. We got the following results:

$\begin{array}{cc}\text { Dosage }(\mathrm{ng} / \mathrm{Kg} / \mathrm{min}) & \text { Infusion rate }(\mathrm{mL} / \mathrm{hr}) \\ 2 & 0.48 \\ 4 & 0.96 \\ 6 & 1.44 \\ 8 & 1.92 \\ 10 & 2.40\end{array}$

\section{Conclusion}

We have shown that our dilution protocol keeps the recommended dilution ratios, and the required solution $\mathrm{pH}$, for very small dosages of epoprostenol, using the same diluent vial. Our method allows a correct and safe administration of epoprostenol in VLBW infants and it is applicable to infants with a weight as low as $500 \mathrm{~g}$. We speculate it could be useful also for other drugs which dilution requires fixed parameters $\mathrm{pH}$ related.

\section{Disclaimer}

Before applying this dilution protocol, the physician should check carefully the composition and the concentration of the

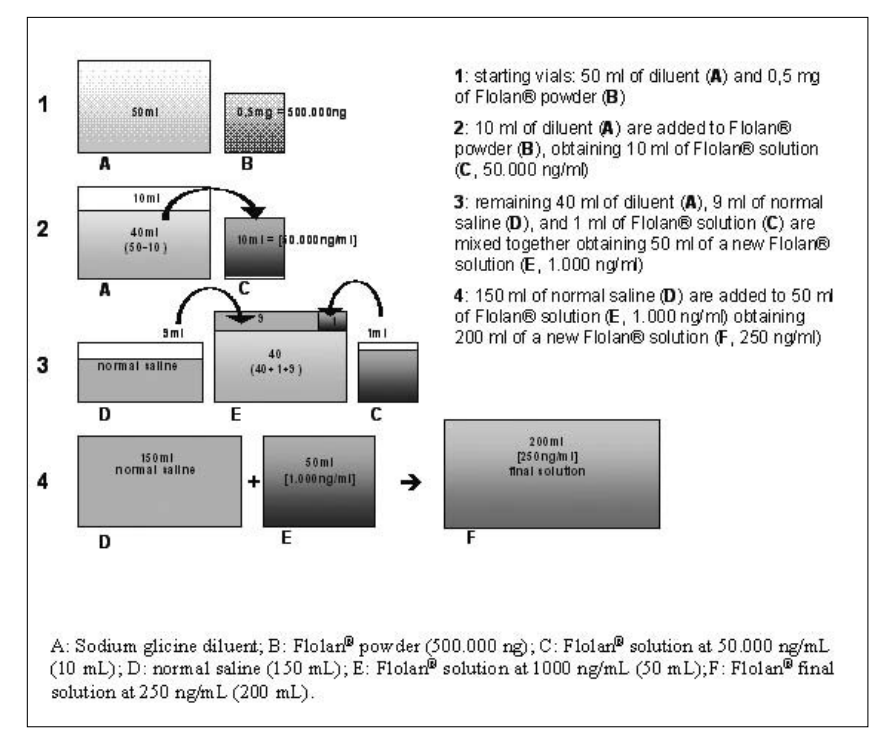

Figure 1.

Dilution protocol of a Flolan® vial containing $0.5 \mathrm{mg}$ with a diluent vial of $50 \mathrm{ml}$.

epoprostenol vials to be used, and obtain updated information from the manufacturer. The Authors and the Publisher do not assume any responsibility for the way in which this protocol is applied.

\section{References}

1 Rubin LJ, Mendoza J, Hood M, et al. Treatment of primary pulmonary hypertension with continuous intravenous prostacyclin (epoprostenol). Results of a randomized trial. Ann Intern Med 1990;112:485-491.

2 Barst RJ, Rubin LJ, Long WA, et al. A comparison of continuous intravenous epoprostenol (prostacyclin) with conventional therapy for primary pulmonary hypertension. The Primary Pulmonary Hypertension Study Group. N Engl J Med 1996;334:296-302.

3 Barst RJ, Maislin G, Fishman AP. Vasodilator therapy for primary pulmonary hypertension in children. Circulation 1999;99:1197-1208.

4 Tzimenatos L, Bond GR. Pediatric Therapeutic Error Study Group. Severe injury or death in young children from therapeutic errors: a summary of 238 cases from the American Association of Poison Control Centers. Clin Toxicol 2009; $47(4): 348-354$.

5 Cushing A, Metcalfe R. Optimizing medicines management: From compliance to concordance. Ther Clin Risk Manag 2007;3(6):1047-1058. 